www.banglajol.info/index.php/JSF

J Sci Foundation, January-June 2012;10(1):1-11

ISSN 1728-7855

\title{
Antimicrobial and Cytotoxic Activities of the Extracts of Glochidion multiloculare
}

\author{
Selina Kabir ${ }^{1}$, A.M. Sarwaruddin Chowdhury ${ }^{2}$, Mohammad A. Rashid ${ }^{3}$ and \\ Choudhury M. Hasan
}

\begin{abstract}
The current study was designed to investigate the antimicrobial and cytotoxic activities of methanol extract (MEGM), petroleum ether fraction (PEFGM), carbontetrachloride fraction (CTFGM), chloroform fraction (CFFGM) and aquous fraction (AQFGM) of stem bark of Glochidion multiloculare (Euphorbiaceae). Antimicrobial activity was evaluated by disc diffusion method and cytotoxic activity by brine shrimp lethality bioassay. In case of antimicrobial screening the CFFGM showed moderate inhibitory activity against $B$. subtilis having the zone size $12 \mathrm{~mm}$ and against Escherichia coli and Escherichia coli were $11 \mathrm{~mm}$, while in the brine shrimp lethality bioassay, the petroleum ether soluble fraction revealed the highest cytotoxicity having $\mathrm{LC}_{50}$ of $3.11 \mu \mathrm{g} / \mathrm{ml}$.
\end{abstract}

Keywords: Glochidion multiloculare, Euphorbiaceae, antimicrobial screening, brine shrimp lethality bioassay

\section{INTRODUCTION}

Glochidion was regarded as a genus of the family Euphorbiaceae, which consists of monoecious, rarely dioecious trees or shrubs. But molecular phylogenetic studies have shown that Phyllanthus is paraphyletic over Glochidion. A recent revision of the family Phyllanthaceae has subsumed Glochidion into Phyllanthus (Hoffmann et al., 2006). Glochidion multiloculare (Roxb. ex Willd.) Muell.-Arg., Phyllanthaceae (synonym: Phyllanthus multilocularis), locally known as Aniatori, Keotomi, Keoura, Paniatori, Pannyaturi is an evergreen shrub or small tree. The plant is found in Bhutan, India, Myanmar, Nepal and Bangladesh. Traditionally many Phyllanthus species are used in

\footnotetext{
${ }^{1}$ Department of Applied Chemistry and Chemical Engineering, Faculty of Engineering and Technology, University of Dhaka, Dhaka-1000

2 Department of Applied Chemistry and Chemical Engineering, Faculty of Engineering and Technology, University of Dhaka, Dhaka-1000

3 Department of Pharmaceutical Chemistry, Faculty of Pharmacy, University of Dhaka, Dhaka- 1000

4 Department of Pharmaceutical Chemistry, Faculty of Pharmacy, University of Dhaka, Dhaka-1000
} 
haemorrhoids, diarrhoea, dysentery, anaemia, jaundice, dyspepsia, insomnia etc. and some of them can induce diuresis (Ghani, 1998). In Chinese traditional medicine Glochidion puberum is used in dysentery, jaundice, leukorrhagia, common cold, sore throat, toothache, carbuncle, furuncle, rheumatic arthralgia (Hu et al., 2004).

Biological investigations of Phyllanthus species revealed that many members of the genus possess anti-tumor promoting ability (Huang et al., 2006; Rajeshkumar et al., 2002; Tanaka et al., 2004), apoptosis inducing ability (Huang et al., 2004; Puapairoj et al., 2005), antiviral activity against hepatitis B virus (Lam et al., 2006; Venkateswaran et al., 1987), antiangiogenic effect (Huang et al., 2006), analgesic effect (Santos et al., 1994, 2000), diuretic effect (Srividya and Periwal, 1995), lipid lowering activity (Khanna et al., 2002), hypocholesterolemic activity (Adeneye et al., 2006), antioxidative effect (Harish and Shivanandappa, 2006; Raphael et al., 2002; Sabir and Rocha, 2008), antidiabetic effect (Adeneye et al., 2006; Raphael et al., 2002; Srividya and Periwal, 1995), antiherpetic activity (Álvarez et al., 2009; Yang et al., 2007), hepatoprotective effect (Harish and Shivanandappa, 2006; Sabir and Rocha, 2008), anti-inflammatory action (Kassuya et al., 2006; Kiemer et al., 2003), antiatherogenic effect (Duan et al., 2005), anti-HIV activity (Notka et al., 2003, 2004; Ogata et al., 1992); antiplasmodial activity (Luyindula et al., 2004), antibacterial activity (Meléndez and Capriles, 2006), hypotensive activity (Leeya et al., 2010; Srividya and Periwal, 1995) etc.

Several secondary metabolites were isolated from different Phyllanthus species, including flavonoids, lignans, alkaloids, triterpenes, phenols and tannins (Calixto et al., 1998; Chang et al., 2003; Ishimaru et al., 1992). Many secondary metabolites were isolated from Glochidion species, including tannins (Chen et al., 1995), glycosides (Otsuka et al., 2003), lignans (Otsuka et al., 2000), terpenoids (Hui and Li, 1976). Previous investigation of Glochidion multiloculare revealed glochidiol, glochilocudiol, glochidone and dimedone (Talapatra et al., 1973).

\section{MATERIALS AND METHODS}

\section{Plants mate rials}

The stem bark of G. multiloculare was collected from Modhupur, Tanghail in the month of April, 2009 and identified by Mr. Sarder Nasir Uddin, Scientific Officer, Bangladesh National Herbarium, Dhaka, where a voucher specimen (DACB-34200) representing this collection has been deposited.

\section{Preparation of extract}

The air dried powdered plant material (1000 g) was successively cold extracted with methanol (7 days) at room temperature with occasional shaking and stirring. The extractives were filtered through fresh cotton plug and followed by whatman no. 1 filter paper. The filtrate were then concentrated by a Buchii rotavapor at low temperature and pressure and afforded methanol (MEGM) extract $(41.7398 \mathrm{~g})$. The cold methanol extract $(10 \mathrm{~g})$ was subjected to Solvent-Solvent partitioning using the protocol designed by Kupchan and modified by Wagene (19). The extract was portioned successively with petroleum ether (PEFGM), carbon te trachloride (CTFGM) and chloroform (CFFGM). 


\section{Antimicrobial Activity Test}

The antimicrobial activities of the crude extracts were determined by the disc diffusion method(Baur,A.W. et al., 1966; Gazi, H.R. et al., 2007; Nahar,K et al., 2008) against the bacterial strains listed in Table-1. These were collected as pure cultures from the Institute of Nutrition and Food Science (INFS), University of Dhaka, Bangladesh.Here Kanamycin (30 $\mu \mathrm{g} / \mathrm{disc}$ ) was used as the standard. The pet-ether, carbontetrachloride,chloroform, aqueous fractions and methanol extract were dissolved separately in chloroform and applied to sterile discs at a concentration of $400 \mu \mathrm{g} /$ disc and carefully dried to evaporate the residual solvent.

\section{Cytotoxic activity test}

For cytotoxicity screening, DMSO solutions of the petroleum ether, carbontetrachloride, chloroform, methanol and aqueous soluble extracts were applied against Artemia salina ${ }^{1}$ in a 1-day in vivo assay. Measured amount of each sample was dissolved in $100 \mu 1$ of DMSO in a vial to get stock solution. Then $50 \mu$ l of solution was added to test tube each containing 5 $\mathrm{ml}$ of seawater and 10 shrimp nauplii. Thus, the final concentration of samples in the No.1 test tube was $400 \mu \mathrm{g} / \mathrm{ml}$. Then a series of solutions of varying concentrations (every time half than previous) were prepared from stock solution by serial dilution me thod. In each case, fresh $50 \mu \mathrm{l}$ DMSO was added to vial (total volume $100 \mu \mathrm{l}$; then shaking it) and from it, $50 \mu 1$ of sample was taken to test tube.

\section{RESULTS AND DISCUSSIONS}

The methanolic extract of the stem bark (MeEGM) of G. multiloculare as well as its petroleum ether (PEFGM), carbon tetrachloride (CTFGM), chloroform (CFFGM) and aquous (AQFGM) soluble fractions were subjected to microbiological screening.

Table 1: Antimicrobial activity of test samples of $G$. multiloculare

\begin{tabular}{|l|c|c|c|c|c|c|}
\hline Test microorganisms & \multicolumn{7}{|c|}{ Diameter of zone of inhibition (mm) } \\
\hline & PEFGM & CTFGM & CFFGM & MeEGM & AQFGM & KAN \\
\hline \multicolumn{7}{|c|}{ Gram Positive Bacteria } \\
\hline Bacillus cereus & 09 & 08 & 10 & -- & -- & 33 \\
\hline B. megaterium & 09 & 08 & 10 & -- & -- & 33 \\
\hline B. subtilis & 09 & 09 & 12 & -- & 07 & 33 \\
\hline Sarcina lutea & 09 & 08 & 10 & -- & -- & 33 \\
\hline \multicolumn{7}{|c|}{ Gram Negative Bacteria } \\
\hline Escherichia coli & 08 & 09 & 11 & -- & -- & 33 \\
\hline Pseud. aeruginosa & 08 & 08 & 10 & -- & 07 & 33 \\
\hline Escherichia coli & 08 & 09 & 11 & -- & 07 & 33 \\
\hline S. typhi & 08 & 08 & 10 & -- & -- & 33 \\
\hline Shigella dysenteriae & 08 & 08 & 10 & -- & 07 & 33 \\
\hline
\end{tabular}


Table 1: Antimicrobial activity of test samples of $G$. multiloculare (Conti.)

\begin{tabular}{|l|l|l|l|l|l|l|}
\hline Sh. boydii & 09 & 07 & 10 & -- & -- & 33 \\
\hline Vibrio mimicus & 09 & 07 & 09 & -- & 07 & 32 \\
\hline V. parahemolyticus & 10 & 08 & 10 & -- & -- & 33 \\
\hline \multicolumn{7}{|c|}{ Fungi } \\
\hline Candida albicans & 10 & 08 & 09 & -- & -- & 32 \\
\hline Aspergillus niger & 10 & 09 & 09 & -- & 07 & 33 \\
\hline $\begin{array}{l}\text { Sacharomyces } \\
\text { cerevaceae }\end{array}$ & 10 & 09 & 10 & -- & 08 & 33 \\
\hline
\end{tabular}

KAN: standard kanamycin disc $(30 \mu \mathrm{g} / \mathrm{disc})$; a diameter of zone of inhibition less than $8 \mathrm{~mm}$ was considered inactive; Pseud. $=$ Pseudomonas

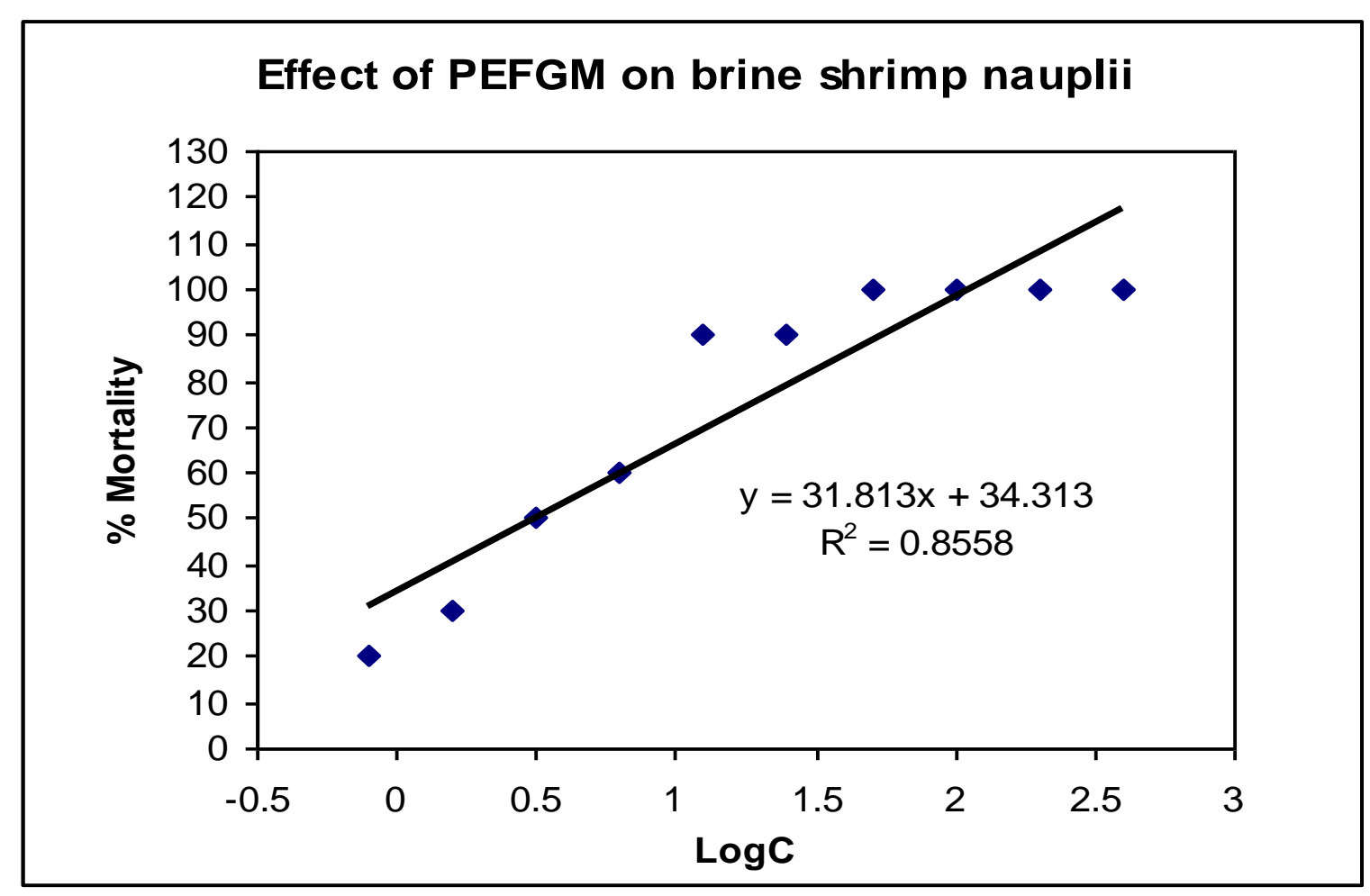

Fig 1: Effect of Petroleum ether soluble fraction of G. multiloculare on brine shrimp nauplii

In this test, the CFFGM of the methanolic extract appeared to be moderate in terms of both zone of inhibition and spectrum of activity. In this study, the zones of inhibition produced by the CFFGM, PEFGM and CTFGM were ranged from 9-12 $\mathrm{mm}, 8-10 \mathrm{~mm}$ and 7-9 $\mathrm{mm}$ respectively (Table 1). 
Table 2: $\mathrm{LC}_{50}$ data of test samples of $G$. multiloculare

\begin{tabular}{|c|c|c|c|}
\hline Test samples & Regression line & $\mathbf{R}^{2}$ & LC $_{\mathbf{5 0}}(\boldsymbol{\mu g} / \mathbf{m l})$ \\
\hline VS & $\mathrm{y}=33.623 \mathrm{x}+66.812$ & 0.9548 & $0.32 \pm 0.12$ \\
\hline PEFGM & $\mathrm{y}=31.813 \mathrm{x}+34.313$ & 0.8558 & $3.11 \pm 0.11$ \\
\hline CTFGM & $\mathrm{y}=34.431 \mathrm{x}+26.048$ & 0.9144 & $4.96 \pm 0.66$ \\
\hline CFFGM & $\mathrm{y}=35.236 \mathrm{x}+19.043$ & 0.9089 & $7.56 \pm 0.11$ \\
\hline MeEGM & $\mathrm{y}=35.437 \mathrm{x}+15.792$ & 0.9387 & $9.23 \pm 0.33$ \\
\hline AQFGM & $\mathrm{y}=28.793 \mathrm{x}+15.081$ & 0.9852 & $16.32 \pm 0.40$ \\
\hline
\end{tabular}

The values of $\mathrm{LC}_{50}$ are expressed as mean $\pm \mathrm{SD}(\mathrm{n}=3)$

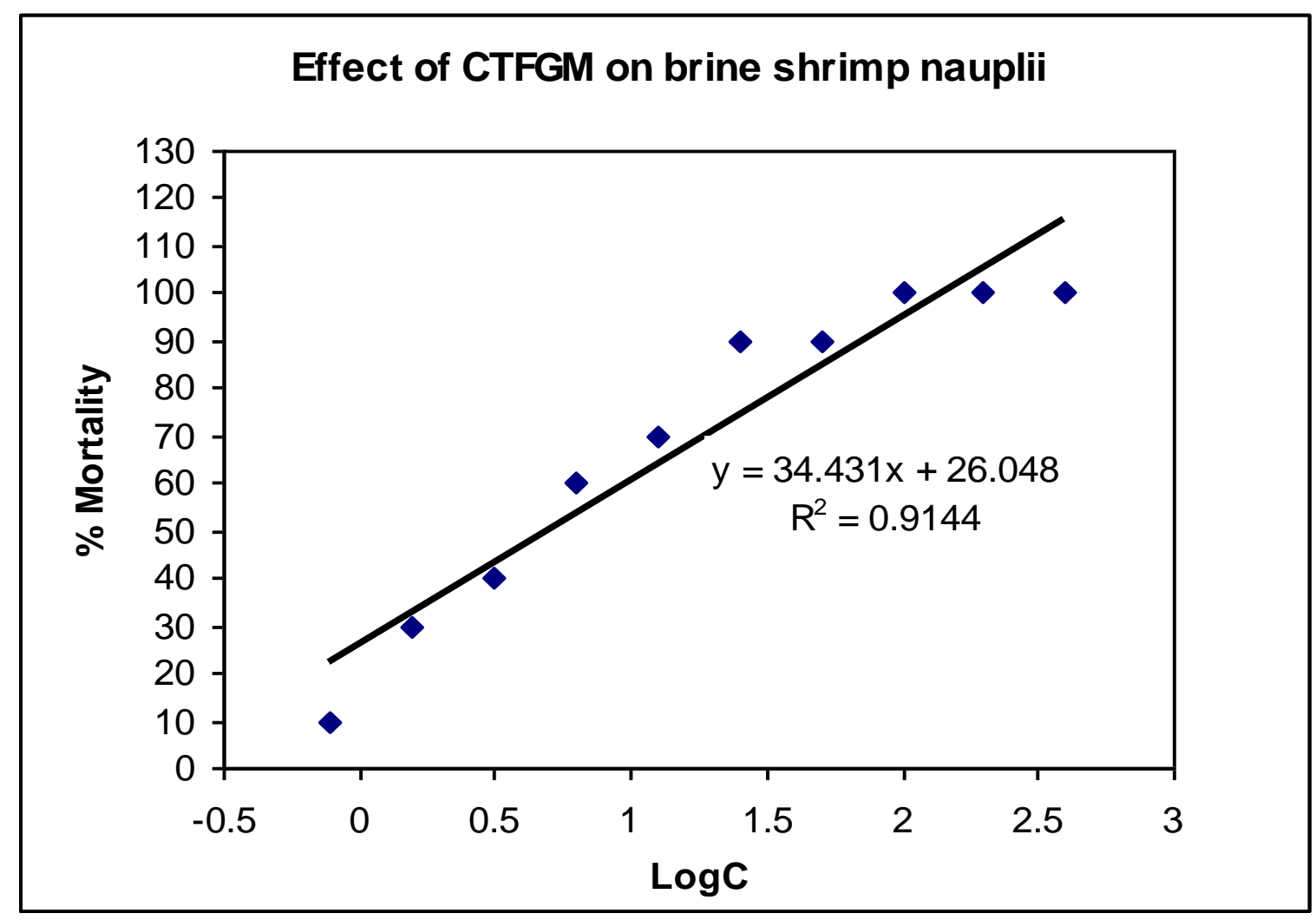

Fig 2: Effect of Carbontetrachloride soluble fraction of G. multiloculare on brine shrimp nauplii 


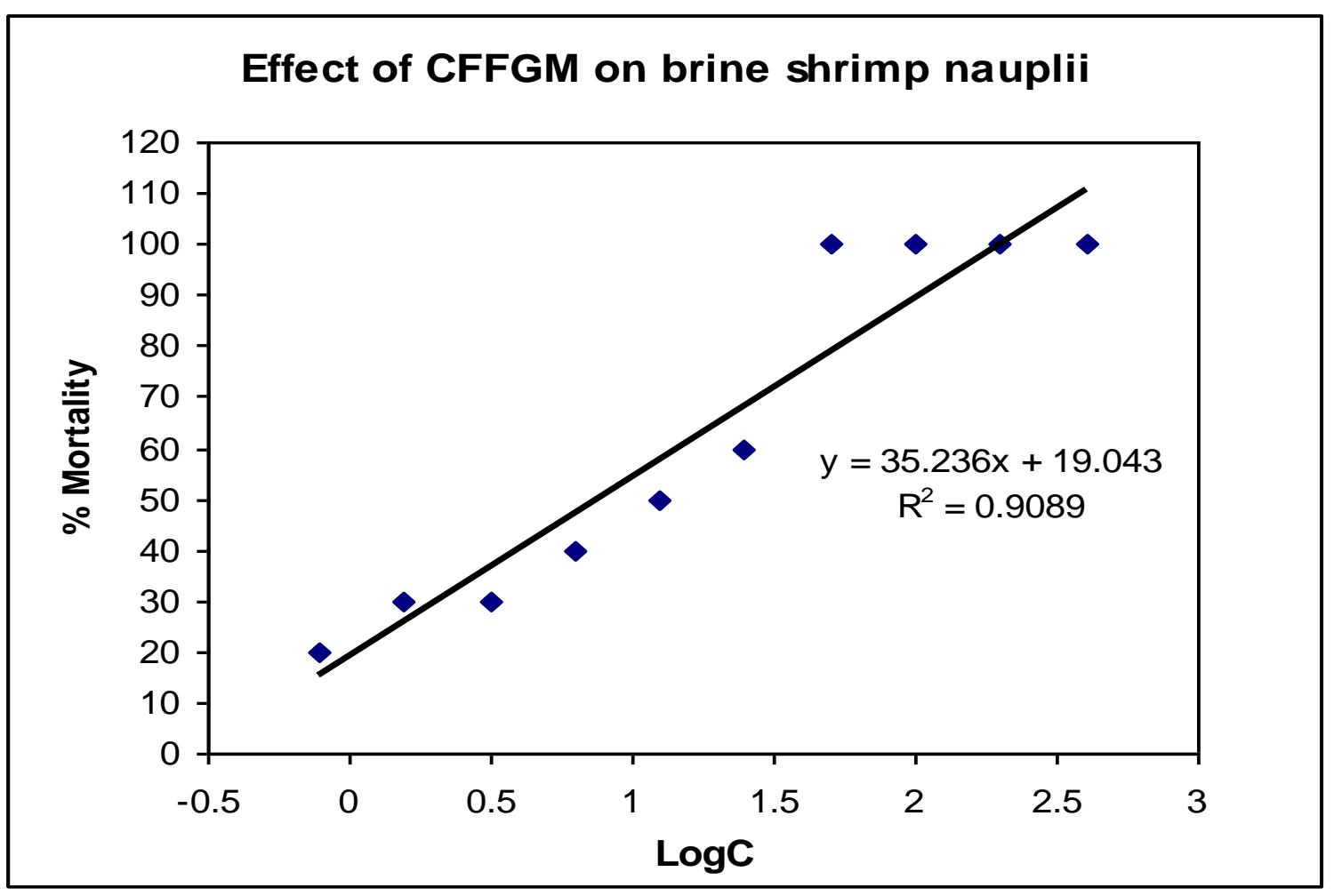

Fig 3: Effect of Chloroform soluble fraction of G. multiloculare on brine shrimp nauplii

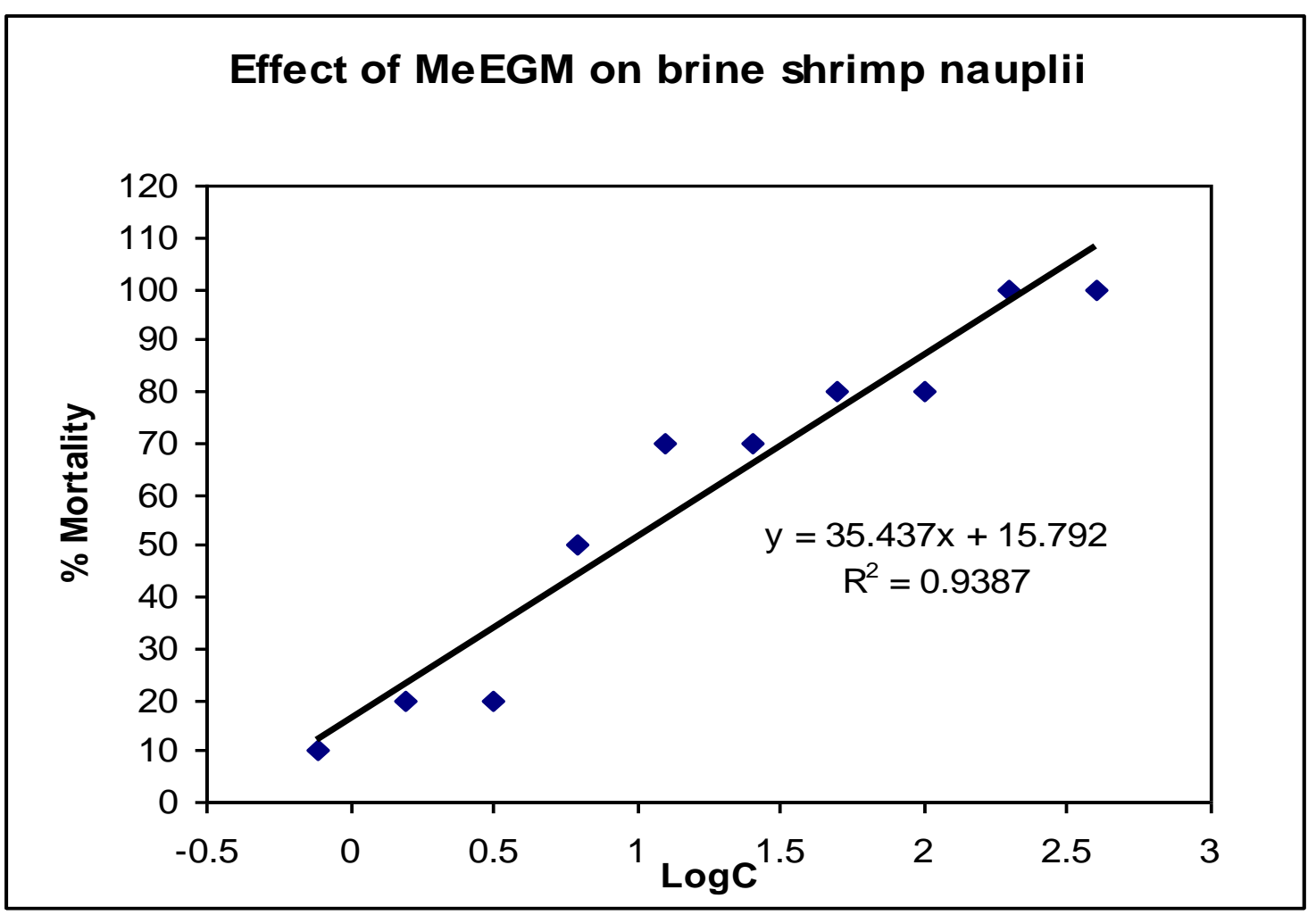

Fig-4: Effect of Methanol soluble extract of $G$. multiloculare on brine shrimp nauplii 
The CFFGM showed moderate inhibitory activity against $B$. subtilis having the zone size 12 $\mathrm{mm}$ and against Escherichia coli and Escherichia coli were $11 \mathrm{~mm}$. This fraction also showed mild inhibitory activity against Bacillus cereus, B. megaterium, Sarcina lutea, Pseudomonas aeruginosa, S. typhi, Shigella dysenteriae, Sh. boydii, V. parahemolyticus, Sacharomyces cerevaceae $(10 \mathrm{~mm}$ each). At the same time, the petether soluble fraction demonstrated mild inhibitory activity against $V$. parahemolyticus, Candida albicans, Aspergillus niger, Sacharomyces cerevaceae (10 mm each). The CTFGM and AQFGM of $G$. multiloculare exhibit the least activity against any microbe. The MeEGM showed no activity.

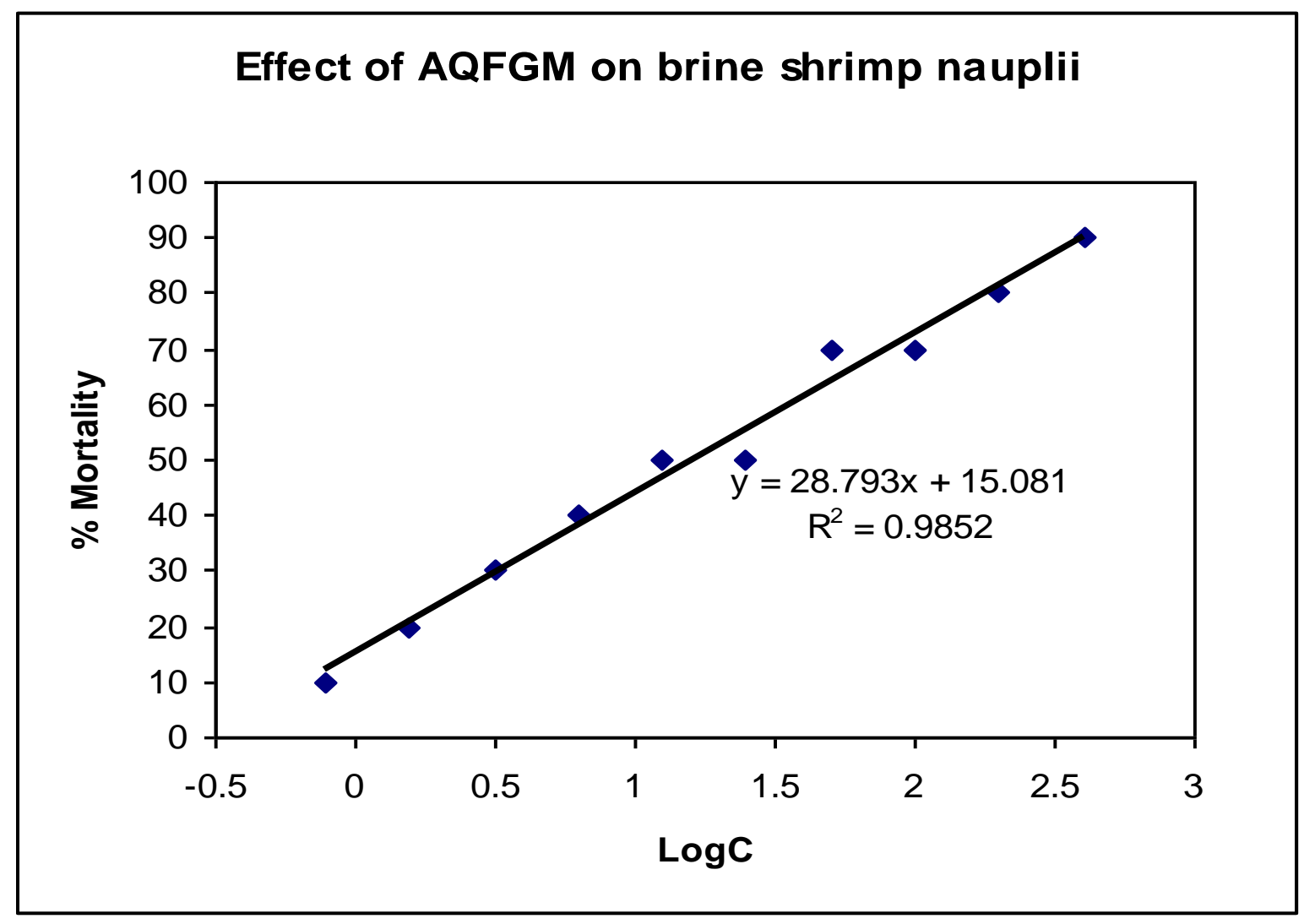

Fig-5: Effect of Aquous soluble fraction of $G$. multiloculare on brine shrimp nauplii

Following the procedure of Meyer et al. 1982, the lethality of the methanol soluble extract (MeEGM) of G. multiloculare as well as its petroleum ether, carbon tetrachloride, chloroform and aquous soluble fractions to brine shrimps were determined and the result are summarized in Table $2 \& 3$.

In the brine shrimp lethality bioassay, the petroleum ether soluble fraction revealed the highest cytotoxicity having $\mathrm{LC}_{50}$ of $3.11 \mu \mathrm{g} / \mathrm{ml}$. The degree of lethality was directly proportional to the concentration of the extract ranging from the lowest concentration $(0.20$ $\mu \mathrm{g} / \mathrm{ml})$ to the highest concentration $(100 \mu \mathrm{g} / \mathrm{ml})$. Maximum mortality took place at a concentration of $100 \mu \mathrm{g} / \mathrm{ml}$, whereas least mortality was observed at $0.20 \mu \mathrm{g} / \mathrm{ml}$. 
In comparison with positive control (vincristine sulphate), the cytotoxicity exhibited by the extractives was promising. These bioactivities exhibited by the plant extractives substantiate the folk uses of the plant in various diseases.

Table-3: Effect of methanol extract, petroleum ether, carbon tetrachloride, chloroform and aqueous soluble fractions of $G$. multiloculare on brine shrimp nauplii

\begin{tabular}{|c|c|c|c|c|c|c|c|c|c|c|c|}
\hline \multicolumn{12}{|c|}{ Glochidion multiloculare } \\
\hline \multirow{2}{*}{$\begin{array}{l}\text { Conc.( } \\
\text { C) } \\
(\mu \mathrm{g} / \mathrm{ml})\end{array}$} & \multirow[b]{2}{*}{$\begin{array}{l}\log \\
\text { C }\end{array}$} & \multicolumn{5}{|c|}{$\%$ Mortality } & \multicolumn{5}{|c|}{$\mathrm{LC}_{50}(\mu \mathrm{g} / \mathrm{ml})$} \\
\hline & & $\begin{array}{c}\text { PE } \\
\text { FG } \\
\text { M }\end{array}$ & $\begin{array}{l}\text { CT } \\
\text { FG } \\
\text { M }\end{array}$ & $\begin{array}{c}\text { CF } \\
\text { FG } \\
\text { M }\end{array}$ & $\begin{array}{l}\text { Me } \\
\text { EG } \\
\text { M }\end{array}$ & $\begin{array}{c}\text { AQ } \\
\text { FG } \\
\text { M }\end{array}$ & $\begin{array}{c}\text { PE } \\
\text { FG } \\
\text { M }\end{array}$ & $\begin{array}{l}\text { CTF } \\
\text { GM }\end{array}$ & $\begin{array}{l}\text { CFF } \\
\text { GM }\end{array}$ & $\begin{array}{l}\text { MeE } \\
\text { GM }\end{array}$ & $\begin{array}{c}\text { AQ } \\
\text { FG } \\
\text { M }\end{array}$ \\
\hline 400 & 2.602 & 100 & 100 & 100 & 100 & 90 & \multirow{10}{*}{$\begin{array}{l}3.11 \pm \\
0.11\end{array}$} & \multirow{10}{*}{$\begin{array}{l}4.96 \\
\pm 0.6 \\
6\end{array}$} & \multirow{10}{*}{$\begin{array}{l}7.56 \\
\pm 0.1 \\
1\end{array}$} & \multirow{10}{*}{$\begin{array}{l}9.23 \\
\pm 0.3 \\
3\end{array}$} & \multirow{10}{*}{$\begin{array}{l}16.3 \\
2 \pm 0 . \\
40\end{array}$} \\
\hline 200 & $\begin{array}{c}2.301 \\
0\end{array}$ & 100 & 100 & 100 & 100 & 80 & & & & & \\
\hline 100 & $\begin{array}{c}2.000 \\
0\end{array}$ & 100 & 100 & 100 & 80 & 70 & & & & & \\
\hline 50 & $\begin{array}{c}1.698 \\
9\end{array}$ & 100 & 90 & 100 & 80 & 70 & & & & & \\
\hline 25 & $\begin{array}{c}1.397 \\
9\end{array}$ & 90 & 90 & 60 & 70 & 50 & & & & & \\
\hline 12.5 & $\begin{array}{c}1.096 \\
9\end{array}$ & 90 & 70 & 50 & 70 & 50 & & & & & \\
\hline 6.25 & $\begin{array}{c}0.795 \\
8\end{array}$ & 60 & 60 & 40 & 50 & 40 & & & & & \\
\hline 3.125 & $\begin{array}{c}0.494 \\
8\end{array}$ & 50 & 40 & 30 & 20 & 30 & & & & & \\
\hline 1.5625 & $\begin{array}{c}0.193 \\
8\end{array}$ & 30 & 30 & 30 & 20 & 20 & & & & & \\
\hline 0.78125 & $\begin{array}{c}- \\
0.107 \\
5\end{array}$ & 20 & 10 & 20 & 10 & 10 & & & & & \\
\hline
\end{tabular}

\section{ACKNOWLEDGEMENT}

Authors are grateful to the faculty of Pharmacy, University of Dhaka, Dhaka-1000, Bangladesh for providing laboratory facilities and The Bose Centre for Advanced Study and Research in Natural Sciences, University of Dhaka, Dhaka-1000, Bangladesh for partial financial support to carry out the research work.

\section{REFERENCES}

Adeneye AA, Amole OO, Adeneye AK 2006. Hypoglycemic and hypocholesterolemic activities of the aqueous leaf and seed extract of Phyllanthus amarus in mice. Fitoterapia 77: 511-514

Álvarez ÁL, del Barrio G, Kourí V, Martínez PA, Suárez B, Parra F 2009. In vitro antiherpetic activity of an aqueous extract from the plant Phyllanthus orbicularis. Phytomedicine 16:960-966 
Baur,A.W., W.M.M., Kirby, J.C. Sherris and M. Turek, 1966. Antibiotic susceptibility testing by a standardized single disk method. Am.J. Clin. Pathol. 45, 493-496

Calixto JB, Santos AR, Cechinel Filho V, Yunes RA 1998. A review of the plants of the genus Phyllanthus: their chemistry, pharmacology, and therapeutic potential. Med Res Rev 18:225-258

Chang C-C, Lien Y-C, Liu KCSC, Lee S-S 2003. Lignans from Phyllanthus urinaria. Phytochemistry 63: 825-833

Chen LG, Yang LL, Yen KY, Hatano T, Yoshida T, Okuda T 1995. Tannins of euphorbiaceous plants. XIII: New hydrolyzable tannins having phloroglucinol residue from Glochidion rubrum BLUME. Chem Pharm Bull 43: 2088-2090

Duan W, Yu Y, Zhang L 2005. Antiatherogenic effects of Phyllanthus emblica associated with corilagin and its analogue. Yakugaku Zasshi 125:587-591

Gazi, H.R., Kabir, S., Rahman, M. S., Chowdhury, A. M. S., Begum, B. and Rashid, M. A., 2007. Antimicrobial and cytotoxic activities of the crude extracts of Hopea scaphula,Dhaka Univ. J. Pharm. Sci. 6(2): 131-133.

Ghani A 1998. Medicinal plants of Bangladesh: Chemical constituents and uses. Asiatic Society of Bangladesh

Harish R, Shivanandappa T 2006. Antioxidant activity and hepatoprotective potential of Phyllanthus niruri. Food Chem 95: 180-185

Hoffmann P, Kathriarachchi H, Wurdack KJ 2006. A phylogenetic classification of Phyllanthaceae (Malpighiales; Euphorbiaceae sensu lato). Kew Bull 61: 37-53

Huang S-T, Yang R-C, Lee P-N, Yang S-H, Liao S-K, Chen T-Y, Pang J-HS 2006. Antitumor and anti-angiogenic effects of Phyllanthus urinaria in mice bearing Lewis lung carcinoma. Int Immunopharmacol 6: 870-879

Huang S-T, Yang R-C, Pang J-HS 2004. Aqueous extract of Phyllanthus urinaria induces apoptosis in human cancer cells. Am J Chin Med 32:175-183

Hui W-H, Li M-M 1976. Lupene triterpenoids from Glochidion eriocarpum. Phytochemistry 15:561-562

Ishimaru K, Yoshimatsu K, Yamakawa T, Kamada H, Shimomura K 1992. Phenolic constituents in tissue cultures of Phyllanthus niruri. Phytochemistry 31:2015-2018

Kassuya CAL, Silvestre A, Menezes-de-Lima O Jr, Marotta DM, Rehder VLG, Calixto JB 2006. Antiinflammatory and antiallodynic actions of the lignan niranthin isolated from Phyllanthus amarus. Evidence for interaction with platelet activating factor receptor. Eur J Pharmacol 546: 182-188

Khanna AK, Rizvi F, Chander R 2002. Lipid lowering activity of Phyllanthus niruri in hyperlipemic rats. J Ethnopharmacol 82: 19-22 
Kiemer AK, Hartung T, Huber C, Vollmar AM 2003. Phyllanthus amarus has antiinflammatory potential by inhibition of iNOS, COX-2, and cytokines via the NF- $\kappa$ B pathway. J Hepatol 38: 289-297

Lam WY, Leung KT, Law PTW, Lee SMY, Chan HLY, Fung KP, Ooi VEC, Waye MMY 2006. Antiviral effect of Phyllanthus nanus ethanolic extract against hepatitis B virus (HBV) by expression microarray analysis. J Cell Biochem 97: 795-812

Leeya Y, Mulvany MJ, Queiroz EF, Marston A, Hostettmann K, Jansakul C 2010. Hypotensive activity of an n-butanol extract and their purified compounds from leaves of Phyllanthus acidus (L.) Skeels in rats. Eur J Pharmacol 649: 301-313

Luyindula N, Tona L, Lunkebila S, Tsakala M, Mesia K, Musuamba CT, Cimanga RK, Apers S, De Bruyne T, Pieters L, Vlietinck AJ 2004. In Vitro Antiplasmodial Activity of Callus Culture Extracts from Fresh Apical Stems of Phyllanthus niruri: Part 1. Pharm Biol 42: 512-518

Meléndez PA, Capriles VA 2006. Antibacterial properties of tropical plants from Puerto Rico. Phytomedicine 13:272-276

Meyer, B.N., N.R. Ferringni, J. E., Puam, L.B., Lacobsen, D.E. Nichols and J. L., McLaughlin, 1982. Brine shrimp a convenient general bioassay for active constituents. Planta Med. 45, 31-32.

Nahar,K., Khan,M.G.U., Rahman,M.S., Begum, B. and Rashid,M.A.,2008. Antimicrobial and cytotoxic activities of Bryophyllum daigremontianum. Dhaka Univ. J. Pharm. Sci.7(1): 99-101

Notka F, Meier GR, Wagner R 2003. Inhibition of wild-type human immunodeficiency virus and reverse transcriptase inhibitor-resistant variants by Phyllanthus amarus. Antiviral Res 58: 175-186

Notka F, Meier G, Wagner R 2004. Concerted inhibitory activities of Phyllanthus amarus on HIV replication in vitro and ex vivo. Antiviral Res 64:93-102

Ogata T, Higuchi H, Mochida S, Matsumoto H, Kato A, Endo T, Kaji A, Kaji H 1992. HIV-1 reverse transcriptase inhibitor from Phyllanthus niruri. AIDS Res Hum Retroviruses 8: 1937-1944

Otsuka H, Hirata E, Shinzato T, Takeda Y 2000. Isolation of lignan glucosides and neolignan sulfate from the leaves of Glochidion zeylanicum (Gaertn) A. Juss. Chem Pharm Bull 48: $1084-1086$

Otsuka H, Kijima H, Hirata E, Shinzato T, Takushi A, Bando M, Takeda Y 2003. Glochidionionosides A-D: megastigmane glucosides from leaves of Glochidion zeylanicum (Gaertn.) A. Juss. Chem Pharm Bull 51: 286-290

Panda S, Jafri M, Kar A, Meheta BK 2009. Thyroid inhibitory, antiperoxidative and hypoglycemic effects of stigmasterol isolated from Butea monosperma. Fitoterapia 80: $123-126$ 
Puapairoj P, Naengchomnong W, Kijjoa A, Pinto MM, Pedro M, Nascimento MSJ, Silva AMS, Herz W 2005. Cytotoxic activity of lupane-type triterpenes from Glochidion sphaerogynum and Glochidion eriocarpum two of which induce apoptosis. Planta Med 71:208-213

Rajeshkumar NV, Joy KL, Kuttan G, Ramsewak RS, Nair MG, Kuttan R 2002. Antitumour and anticarcinogenic activity of Phyllanthus amarus extract. J Ethnopharmacol 81: $17-22$

Raphael KR, Sabu MC, Kuttan R 2002. Hypoglycemic effect of methanol extract of Phyllanthus amarus Schum \& Thonn on alloxan induced diabetes mellitus in rats and its relation with antioxidant potential. Indian J Exp Biol 40: 905-909

Sabir SM, Rocha JBT 2008. Water-extractable phytochemicals from Phyllanthus niruri exhibit distinct in vitro antioxidant and in vivo hepatoprotective activity against paracetamol-induced liver damage in mice. Food Chem 111: 845-851

Saleem M 2009. Lupeol, a novel anti-inflammatory and anti-cancer dietary triterpene. Cancer Lett 285: 109-115

Santos AR, De Campos RO, Miguel OG, Filho VC, Siani AC, Yunes RA, Calixto JB 2000. Antinociceptive properties of extracts of new species of plants of the genus Phyllanthus (Euphorbiaceae). J Ethnopharmacol 72:229-238

Santos AR, Filho VC, Niero R, Viana AM, Moreno FN, Campos MM, Yunes RA, Calixto JB 1994. Analgesic effects of callus culture extracts from selected species of Phyllanthus in mice. J Pharm Pharmacol 46: 755-759

Srividya N, Periwal S 1995. Diuretic, hypotensive and hypoglycaemic effect of Phyllanthus amarus. Indian J Exp Biol 33: 861-864

Talapatra SK, Bhattacharya S, Maiti BC, Talapatra B 1973. Structure of glochilocudiol. New triterpenoid from Glochidion multiloculare. Natural occurrence of dimedone. Chem Ind (London, U. K.) 21:1033-1034, apud Chemical Abstracts 80: 48188w

Tanaka R, Kinouchi Y, Wada S-ichi, Tokuda H 2004. Potential anti-tumor promoting activity of lupane-type triterpenoids from the stem bark of Glochidion zeylanicum and Phyllanthus flexuosus. Planta Med 70: 1234-1236

Venkateswaran PS, Millman I, Blumberg BS 1987. Effects of an extract from Phyllanthus niruri on hepatitis B and woodchuck hepatitis viruses: in vitro and in vivo studies. Proc Natl Acad Sci U S A 84:274-278

Yang C-M, Cheng H-Y, Lin T-C, Chiang L-C, Lin C-C 2007. The in vitro activity of geraniin and 1,3,4,6-tetra- $O$-galloyl- $\beta$-D-glucose isolated from Phyllanthus urinaria against herpes simplex virus type 1 and type 2 infection. J Ethnopharmacol 110:555-558 